\title{
Material Memories of Empire: Coming to Terms with German Colonialism
}

The memory of colonialism in Germany has been long-lived and relatively dynamic. This is because Germany's postcolonial period has been shaped by profound ruptures including the Second World War, the Holocaust and the Cold War. This article sketches out the multifaceted collective memory of German colonialism stretching from the loss of the colonies to the present day. In 1959, Theodor Adorno famously admonished Germans for not "coming to terms" with their National Socialist past in the postwar period, a statement which many intellectuals and "ordinary Germans" have taken to heart since then. ${ }^{1}$ But has there been a comparable "coming to terms" with a colonial past?

The German case is important for scholars' understanding of wider European colonialisms and postcolonialisms because it is at once an example and an aberration.

Although some academics have revived Hannah Arendt's work on the origins of totalitarianism and sought the origins of Nazism in colonial wars at the beginning of the twentieth century, this is a problematic thesis which has come up against a number of well-founded counter-arguments. ${ }^{2}$ Extreme violence and

1 Theodor Adorno, "What does coming to terms with the past mean?," in G. Hartman, Bitburg in Moral and Political Perspective (Bloomington: Indiana University Press, 1986), 114-129.

2 Jürgen Zimmerer has been the most prolific recent proponent of this argument; see for example "Krieg, KZ und Völkermord in Südwestafrika. Der erste deutsche Genozid," in Jürgen Zimmerer and Joachim Zeller, Völkermord in Deutsch-Südwestafrika (Berlin: Ch. Links, 2003), 4563; see also Mark Mazower, Dark Continent (New York: Random House, 1998), 71-72; Marcia Klotz, "Global Visions: From the Colonial to the National Socialist World," European Studies Journal 16,2 (Fall 1999): 37-68; David Furber and Wendy Lower, "Colonialism and Genocide in Nazi-Occupied Poland and Ukraine," in A. Dirk Moses, Empire, Colony, Genocide (New York/Oxford: Berghahn, 2008): 372-400. Convincing arguments against this "continuity thesis" have been presented in Isabel Hull, Absolute Destruction (Ithaca/London: Cornell University Press, 2005); Birthe Kundrus, "Kontinuitäten, Parallelen, Rezeptionen,” Werkstatt Geschichte 43 (2006): 45-62; Pascal Grosse, "What does German colonialism have to do with National Socialism? A conceptual framework," in Eric Ames, Marcia Klotz, and Lora Wildenthal, Germany's Colonial Pasts (Lincoln: University of Nebraska Press, 2005), 115-134; Sebastian Conrad, Deutsche Kolonialgeschichte (Munich: C.H. Beck, 2008), 96-106; Stephan Malinowski and Robert Gerwarth, “Hannah Arendt”s Ghosts," Central European History 42 (2009), 279-300. For further discussion of the debate, see Volker Langbehn and Mohammad Salama, German Colonialism (New York: Columbia University Press, 2011). 
racism were not unique to the German colonies, and, as with other European powers, the shape of colonial rule varied across the different areas of empire. As much as it may have influenced German racialist thinking, colonial violence in itself does not explain why other colonial powers did not develop into totalitarian societies. Moreover, not all former colonialists integrated themselves into the NSDAP seamlessly. Certainly, both Nazism and colonialism made use of concepts of "race," "empire," and to some extent also "colonialism," but in very different contexts. ${ }^{3}$ Finally, in numerous aspects, the colonial period itself was similar to and indeed entangled with other European colonial powers' patterns of governance, as Ulrike Lindner, for example, has shown with respect to British and German colonial powers in Africa. ${ }^{4}$

Part of what makes the German case unique is not only that the colonial period was so short, but rather that it was cut short. On the one hand, this meant that Germany never had the experience of postcolonial migration, of hundreds of thousands of ex-colonial migrants moving to live and work in the metropole, as has been the case in France and Britain. On the other hand, some scholars have argued that the colonial past still influences Germany's multicultural present to varying degrees. ${ }^{5}$ Germany's original period of decolonization began earlier than that of many other European nations, giving it considerable time and impetus to develop a collective memory of colonialism after the fact, a memory which is

3 Uta Poiger thus makes a valid plea for viewing German history as "imperial" history, but this is not contingent upon classifying the German-Herero war as "genocide." U. Poiger, "Imperialism and Empire in Twentieth-Century Germany," History and Memory 17,1-2 (Spring-Summer 2005): 117-143. This is echoed by Pascal Grosse in "From Colonialism to National Socialism to Postcolonialism," Postcolonial Studies 9,1 (2006): 48 and Shelley Baranowski in Nazi Empire (Cambridge: Cambridge University Press, 2011), 3.

4 Ulrike Lindner, Koloniale Begegnungen (Frankfurt am Main/New York: Campus, 2011).

5 See, e.g., Monika Albrecht, "Postcolonialism and Migration into Germany's Colonial Past," German Life and Letters 65,3 (July 2012): 363-377; Patrice Nganang, “Autobiographies of Blackness in Germany," in Ames, Klotz, and Wildenthal, Germany's Colonial Pasts, 227-240; Kien Nghi Ha, Nicola Lauré al-Samarai and Sheila Mysorekar, "Einleitung," in Ha, al-Samarai and Mysorekar, re/visionen (Münster: Unrast, 2007), 9-21; Hito Steyerl, Encarnación Gutiérrez Rodríguez and Kien Nghi Ha, Spricht die Subalterne deutsch?, $2^{\text {nd }}$ edition (Münster: Unrast, 2012); María do Mar Castro Varela and Nikita Dhawan, "Mission Impossible," in Julia Reuter and Paula-Irene Villa, Postkoloniale Soziologie (Bielefeld: Transcript, 2010), 303-330; Cyber-Nomads/Öffentlichkeit gegen Gewalt, The Black Book (Frankfurt am Main/London: IKO, 2004); Maureen Maisha Eggers, Grada Kilomba, Peggy Piesche and Susan Arndt, Mythen, Masken und Subjekte (Münster: Unrast, 2006); Sara Lennox, "Postcolonial Writing in Germany," in Ato Quayson, Cambridge History of Postcolonial Literature (Cambridge: Cambridge University Press, 2012), 620 - 648. For a discussion of different German "postcolonialisms," see Britta Schilling, “German Postcolonialism in Four Dimensions,” Postcolonial Studies 18,4 (2015): 427-439. 
now one or even two generations ahead of that of other major European powers, but perhaps more hidden from public space. Although the scope of German colonialism discussed, for example, at international conferences has expanded, most historians still see 1945 as a stopping point, claiming that afterwards there existed only a period of colonial 'amnesia'. ${ }^{6}$ This article proposes a different periodization, one which transcends the conventional breaks marked by the Nazi takeover and the end of the Second World War.

\section{Memory in Germany: a (material) re-periodization}

Looking at both historical and theoretical aspects, it addresses a problem in traditional historiography by exploring how long, following the end of formal claims to overseas territories, a ‘collective memory' of German colonialism continued to exist, what forms it assumed, and how and why these forms changed over time. This paper summarizes the most important nodes in this memory narrative, which are explained more fully in the book, Postcolonial Germany. ${ }^{7}$ But, unlike other lieux-de-mémoire-like compilations, ${ }^{8}$ the research also opens up valuable new opportunities for considering the relationship between human memory and material culture, how things make us think about the past. In our own rapidly evolving digital age, which replaces material objects with ephemeral renditions (one has only to think of the evolution of the book), the relationship between the physical and the psychological may itself soon be a figment of the past, making its investigation all the more valuable. It is the latter goal on which this article focuses.

Recent attempts to define the relationship between people and artefacts have shown how memory objects are a unique means of re-experiencing the past in the present. In his work on memory and material culture, Andrew Jones, for example, argues that "we can no longer simply treat objects purely

6 The term "Amnesie" has been used by Reinhart Kößler and others to describe the current state of awareness of colonialism in Germany. Kößler, "Kolonialherrschaft-auch eine deutsche Vergangenheit”, in Lutz and Gawarecki, Kolonialismus und Erinnerungskultur (Munster: Waxmann, 2005), 33. Lora Wildenthal also refers to a "repudiation or amnesia" of imperial ambitions after 1945 in her essay, "Notes on a History of 'Imperial Turns' in Modern Germany," in Antoinette Burton, After the Imperial Turn (Durham/London: Duke University Press, 2003), 145-156.

7 Britta Schilling, Postcolonial Germany (Oxford: Oxford University Press, 2014).

8 For example, most recently, Jürgen Zimmerer, Kein Platz an der Sonne (Frankfurt am Main: Campus, 2013). 
as symbolic media; rather the materiality of objects is best seen as impinging on people sensually and physically at a fundamental level." $"$ This primacy of the material in social and cultural history has also been evoked in different contexts by sociologist Arjun Appadurai, historical anthropologist Nicholas Thomas, historian Carolyn Steedman, archaeologist Chris Gosden and anthropologist Chantal Knowles. ${ }^{10}$ In German history, the function of material objects has most influenced studies on museums, exhibitions, and the history of German ethnology, including the more recent debates of the restitution of ethnographic objects and human remains housed in Berlin museums. ${ }^{11}$ This article expands this research by refocusing the debate to consider how objects of memory function not just as symbols in public spaces such as museums, but as "physical traces"12 of the past in private spaces such as the home.

What makes material culture a particularly useful lens through which to investigate the colonial past? Firstly, as Karen Harvey writes, “unlike 'object' or 'artefact', 'material culture' encapsulates not just the physical attributes of an object, but the myriad and shifting contexts through which it acquires meaning. Material culture is not confined to objects that people make, use and throw away; it is an integral part of-and indeed shapes-human experience." over, as Arjun Appadurai has argued, objects, or commodities, have "social lives." 14 They are produced, disseminated and consumed; they can be maintained, displayed and showcased, or they can be allowed to decay. The study of objects thus always includes the study of people's relationship to them and the attitudes and ideologies which inform this relationship. Furthermore, as colonial objects move in and out of "commodity phases", to borrow Igor Kopytoff's

9 Andrew Jones, Memory and Material Culture (Cambridge: Cambridge University Press, 2007), 19.

10 Arjun Appadurai, The Social Life of Things (Cambridge: Cambridge University Press, 1986); Carolyn Steedman, “What a Rag Rug Means," Journal of Material Culture 3,3 (Nov. 1998): 259281; Nicholas Thomas, Entangled Objects (Cambridge, MA/London: Harvard University Press, 1991); Chris Gosden and Chantal Knowles, Collecting Colonialism (Oxford/New York: Berg, 2001). 11 H. Glenn Penny and Matti Bunzl, Worldly Provincialism (Ann Arbor: University of Michigan Press, 2003); Penny, Objects of Culture (Chapel Hill/London: University of North Carolina Press, 2003). Holger Stoecker, Thomas Schnalke and Andreas Winkelmann, Sammeln, Erforschen, Zurückgeben? (Berlin: Christoph Links, 2013); Stoecker, "Knochen im Depot," in Jürgen Zimmerer, Kein Platz an der Sonne (Frankfurt a.M.: Campus, 2013), 442-457. The issue has also been covered extensively in the German media.

12 Jones, Memory and Material Culture, 19.

13 Karen Harvey, “Introduction," in Harvey, History and Material Culture (Abingdon: Routledge, 2009), 3.

14 Arjun Appadurai, "Introduction: commodities and the politics of value”, in Appadurai, Social Lives, 3-63. 
phrase, we can learn how the value of colonial objects has changed over time, as well as how colonial memory itself has been commodified. ${ }^{15}$ And finally, objects can travel; they can cross national boundaries but also the boundaries between public and private space. Essentially, it is material objects' ability to generate meaning both to larger collectives as well as to individuals which makes them such an important element in any study of colonial memory. This paper thus argues that colonial memory was intimately bound to objects of material culture in the former German metropole, but also suggests how colonial material culture remains a contested site of national heritage in many of the former colonies. I will now briefly sketch out the histories of four objects of colonial memory which were influential in determining the meaning of the colonial past in Germany from the end of the First World War to the late 1960s.

\section{1915-1925: Afrikabücher/Africa-books}

Attempts to memorialize German colonialism start in the colonial period itself but pick up dramatically after the loss of the colonies. One of the earliest nodes of colonial memory which traversed the private and public spheres was the Afrikabuch, or Africa-book. Afrikabuch or Kolonialbuch, an analogous expression, are not terms that are found, for example, in literary encyclopaedias such as Hiersemann's Lexikon des Gesamten Buchwesens or Hiller and Füssel's Wörterbuch des Buches. They are, nevertheless, terms which were frequently used in everyday parlance during the 1920s and, in the specific case of Afrikabuch, still used today. Indeed, "Africa-books," published travel accounts and geographies of Africa for a European audience, have been in existence for hundreds of years. One of the most notable examples, said to be the first early modern European geography of the continent, was written by the Moroccan diplomat Leo Africanus in the sixteenth century. ${ }^{16}$ Afrikabücher published between 1915 and 1925 were therefore certainly not the first ones to appear on the scene. They were, however, the first ones in which we clearly have a sense of the book representing the memory of a bygone era, written during a time when Germans not only were not able to travel much abroad, but were actually banned from entering some of the former colonies in Africa. These books laid the groundwork for a genre that continued to bloom all through the 1920s and well into the Nazi peri-

15 Igor Kopytoff, "The cultural biography of things: commoditization as process", in Appadurai, Social Lives, 64-94; also Appadurai, “Introduction”, 13, 15-28.

16 See Natalie Zemon Davis, Trickster Travels (London: Faber, 2007). 
od. Indeed, many of these books were reissued in the later 1930s because of their nationalist arguments and memories of a German Reich spanning the globe.

Perhaps the most successful fictionalized Afrikabuch of all time was Hans Grimm's novel Volk ohne Raum, first published in 1926, with 480,000 copies in print by $1940 .{ }^{17}$ It was in many ways the culmination of an almost ten-year tradition of German non-fiction books about the former colonies. The story is of a young man who, frustrated with living in an overcrowded and industrialized Germany, finds fulfilment as a farmer in prewar German Southwest Africa. Known to contemporaries as "the German Kipling," Grimm inspired a generation of readers by drawing from his experiences as a journalist and businessman in South and Southwest Africa. ${ }^{18} \mathrm{He}$ was one of the most fervent adherents to the nineteenthcentury idea of Lebensraum, claiming that the German race urgently needed space to expand. Indeed, Grimm's novel was more than just light entertainment. His very motto, Volk ohne Raum, was used by the Nazis to describe colonial living space in the East. ${ }^{19}$ But it would hardly have been possible without the rise in the number of Afrikabücher making their way into German homes before and during Grimm's drafting of the story.

As a medium, the Afrikabuch combines both the "communicative" and "cultural" memory of the period. ${ }^{20}$ It lies at the intersection of oral and written forms of culture, combining the traditional elements of storytelling prevalent in settler society in the colony and the more permanent elements of the written word and popular literature in the metropole. Like communicative memory as defined by Jan and Aleida Assmann, stories in the Afrikabuch are often tales retold, constructed in relation to others who have a common conception of the past, that is, the community of white settlers in Africa. ${ }^{21}$ Thus, these narratives often include digressions, tales related from second-hand knowledge, or even local rumours and myths. Parts of Afrikabücher are told as campfire stories, with a degree of truth but also some room for embellishment, part of a local tradition

17 Donald Ray Richards, The German Bestseller in the 20th Century (Bern: Lang, 1968).

18 G. H. Danton, "Hans Grimms Volk ohne Raum," Monatshefte für deutschen Unterricht 27,2 (Feb. 1935): 37. See also Woodruff Smith, “The Colonial Novel as Political Propaganda," German Studies Review 6,2 (May 1983): 215-235.

19 Konrad Jarausch and Michael Geyer, Shattered Past (Princeton: Princeton University Press, 2003), 207; Jürgen Zimmerer, “Colonialism and the Holocaust," Development Dialogue 50 (Dec. 2008): 96.

20 Jan Assmann and Jan Czaplicka, “Collective Memory and Cultural Identity,” New German Critique 65 (Spring-Summer 1995): 126.

21 Assmann and Czaplicka, "Collective Memory and Cultural Identity”, 127. 
of telling "stories."22 Such storytelling was also frequent in POW camps during and after the war, where a number of authors found their inspiration for writing. ${ }^{23}$ At the same time, a number of Afrikabuch authors were attempting to fix the "shifting horizon" of this form of communicative memory, memorializing it in a more permanent way for future generations through a "cultural" formation: the medium of the written word and the physical book itself. ${ }^{24}$ The Afrikabuch acts as a textual and physical monument to the past, a symbol for an eternal, or timeless, unalterable rendition of history, as well as an expression of a $\mathrm{Ge}$ meinschaft, or a national identity. ${ }^{25}$ The need to memorialize and monumentalize German experiences in Africa stemmed from the fear that the actual era of German colonialism was over.

Afrikabücher are fascinating documents in terms of textual analysis, but we also gain additional insights when we read them not just as texts but as material objects. Afrikabücher can be seen as conforming to the most avant-garde trends which fashioned books as objects of mass consumption. Many of these books were advertised to "young and old alike," reflecting the new desire to provide literature for greater parts of the population, particularly children and young people. ${ }^{26}$ They also made use of new advances in reprographic technology which allowed for inclusion of a far greater number of photographs, pictures, or drawings. The prolific author Hans Anton Aschenborn's Afrikanische Buschreiter, for example, boasts 41 drawings by the author, and his Farm im Steppenlande includes as many as one hundred photographs. Richard Hennig's Sturm und Sonnenschein in Deutsch-Südwest features 47 colored and black-and-white photos, sketches, and watercolors. The inclusion of more visual material was also a response to the growing appeal of media such as illustrated magazines and film. ${ }^{27}$ Graphically intricate covers bearing exotic scenes were meant to quickly attract potential readers. Many Afrikabuch covers, such as August Hauer's Kumbuke, featured colorful renditions of the African landscape and its people. Their outward presentation thus already promised relatively inexpensive es-

22 Otto Inhülsen, Wir ritten für Deutsch-Ostafrika (Leipzig: V. Hase \& Koehler, 1926), 124-125; H. R. Schneider-Waterberg, Der Wahrheit eine Gasse (Swakopmund: Gesellschaft für Wissenschaftliche Entwicklung, 2006), 18.

23 Karl Koch, Im toten Busch (Leipzig: Voigtländer, 1922), foreword.

24 Assmann and Czaplicka, "Collective Memory," 127.

25 Cf. Jan Assmann, “Stein und Zeit. Das 'monumentale’ Gedächtnis der altägyptischen Kultur,” in Jan Assmann and Tonio Hölscher, Kultur und Gedächtnis (Frankfurt am Main: Suhrkamp, 1988), $90-91$.

26 Buchhändlergilde-Blatt 10 (1925): 175.

27 Berthold Brohm, "Das Buch in der Krise. Studien zur Buchhandelsgeschichte der Weimarer Republik,” Archiv für Geschichte des Buchwesens 51 (1999): 272. 
capism. At Christmas, Easter, and other special occasions, Afrikabücher were advertised as special gifts at a range of prices. General von Lettow-Vorbeck's Meine Kriegserinnerungen aus Ostafrika, for example, was offered by Koehler at 28.50 marks, 35 marks fully bound; his Heia Safari!, for a younger audience, was offered to booksellers at 13.50 marks fully bound. ${ }^{28}$ Kriegserinnerungen was thus in the same price range as works by Goethe. ${ }^{29}$

Afrikabücher published during the first half of the 1920s were volumes which could be valued not only for their lively stories and aesthetic appeal, but also for their underlying political messages. They challenged the accusation of Germans being bad colonialists, which had been suggested by the British Blue Book ${ }^{30}$ and was used as justification for removing the colonies from German possession. Instead of portraying German colonialists as violent perpetrators, Afrikabücher used tales of internment, loss and decline to cast Germans in the role of victims. A central element in all of these accounts is explaining the meaning of the Heimat (home) abroad, or zweite Heimat (second home), to those who had never experienced or felt any allegiance to it. They offered a glimpse into the community of German Afrikaner who felt let down by an unjust peace accepted by the Weimar government and was now struggling to survive. Whilst offering these more emotional appeals, Afrikabücher illustrated everyday life abroad and educated readers in the skills and knowledge needed for life in the bush. They sought to excite younger readers with their memories of a golden age, which, in the mid-1920s, some authors hoped could be reclaimed. By imbuing their audience with a sense of nostalgia for a "lost paradise,"31 authors used their personal experiences in the former colonies as political propaganda. It is this quality which made their books attractive to the German readership not only during the early interwar period, but ensured their popularity in years to come.

In both implicit and explicit ways, the rhetoric of remembering and forgetting infuses the texts of Afrikabücher. Indeed, the very medium of text and words, and the more tangible objects of manuscripts and paper become highly significant to authors. When Karl Angebauer is forcibly removed from Southwest Africa, his first instinct is to swear to return. In the face of financial hardship, however, he chooses a different route: he writes about what he has lost. ${ }^{32}$ For

28 Buchhändlergilde-Blatt 3 (1920): 68.

29 Buchhändlergilde-Blatt 3 (1920): back cover.

30 South-West Africa Administrator's Office, Report on the Natives of South-West Africa and their Treatment by Germany (London: His Majesty's Stationery Office, 1918) [British Parliamentary Papers Cd. 9146].

31 Hans Anton Aschenborn, Die Farm im Steppenlande (Neudamm: Neumann, 1925), 7.

32 Karl Angebauer, Ovambo (Berlin: Scherl, 1927), 24-26. 
Otto Inhülsen, it was so important to keep a record of his time in Africa alive that he smuggled his notes and diaries out of East Africa in a suitcase with a false base. ${ }^{33}$ Grete Kühnhold instead regrets having to cede "a few small books with scientific observations and notes on my travels in Kamerun" to British forces upon leaving. ${ }^{34}$ On an even more elemental level, several works reference the Swahili word Kumbuke, or "please remember." 35 Memory was thus enmeshed with the very language of the former African homeland. As much as some books were dedicated to the memory of lives and comrades lost, then, they were also dedicated to a lost time and place.

The Afrikabücher discussed here were just the beginning of a genre, works which prepared the way for a revival of Africa-centered and colonial literature in years to come. Some may even have helped establish prominent publishing houses which later specialized in travel and adventure literature, such as the Safari Verlag, established in $1921 .^{36}$ In any case, every time Afrikabücher were read, every time children and adults leafed through the illustrated pages or gazed at the colorful covers, the memory of the German colonial past was "recharged" through the cultural framework of the present, and the memory of colonialism kept alive. This was the period during which most of the myths and legends concerning Germans in the African colonies were born. Interestingly, it was also a time in which many of these myths were not yet reified, and we see a degree of ambiguity on issues such as the loyalty of African subjects, the treatment of German POWs, and the prospects of Germans returning to the colonies in the future.

\section{1925-1935: Colonial wares/Kolonialwaren}

A second node of material memories of empire in Germany is objects linked to the economic wealth (real or imagined) from the former colonies. Perhaps the best way of understanding their circulation and multiple uses is through the phenomenon of the colonial ball. The colonial ball in Germany reached its peak between the mid-1920s and mid-1930s. At this point, societies like the German Colonial Society (DKG) were in full stride campaigning for colonial revisionism in

33 Inhülsen, Wir ritten für Deutsch-Ostafrika, 212-213.

34 Grete Kühnhold, In Friedens- und Kriegszeiten in Kamerun (Berlin: Scherl, 1917), 66.

35 August Hauer, Kumbuke, 4th edn (Berlin: Hobbing, 1926); Prüße, Zwanzig Jahre Ansiedler in Deutsch-Ostafrika (Stuttgart: Strecke \& Schröder, 1929), 270.

36 Wolfgang Schwerbrock, Hans Thiekötter, and Wilhelm Lehmann, Safari Verlag 1921-1961 (Berlin: Safari, 1961), 8. 
Germany. We can chart the rising popularity of colonial issues by looking, for example, at the membership figures for the Women's League of the German Colonial Society (FDKG). Despite the economically and politically volatile situation during the Weimar Republic, membership rose steadily. Particularly after 1925, when Tanganyika Territory was reopened for German settlement and there appeared to be renewed hope for re-appropriation of the former colonies, colonial organizations won new members. Economically, Germany at this point was also recovering from the inflation crisis of 1923 with the help of the Dawes Plan introduced the following year. In 1930 the Women's League reached the highest membership hitherto at $20,560 .{ }^{37}$ Four years later the number had risen to $26,600 .{ }^{38} \mathrm{In}$ the meantime, 270 local chapters of the FDKG had been founded-over twice as many as in 1933-of which 40 were in Africa. ${ }^{39}$ By 1936, the year of its incorporation into the Nazi Party's Reich Colonial League (RKB), FDKG membership had doubled compared with the figure for 1928 and was 7.5 times higher than in its founding year, $1906 .^{40}$ This "popularization" was attributable to a large extent to the colonial propaganda spread by the Women's League and the larger DKG. Despite the increase in membership numbers, however, the class structure of the leadership remained as middle- and upper-class as ever.

The loss of property and profits which had been, after all, the mainstay of the German overseas merchant elite and had always been at the heart of the German colonial project, left a gaping hole in the former colonialists' sense of identity. Colonial balls were the ideal means of recreating the colonial dream for middle- and upper-class Germans. ${ }^{41}$ They can be read as an attempt to compensate for the loss of the colonies by arranging colonial and pseudo-colonial objects, or symbols, in a dream-space, and then "performing" the dream. Essential to this dream was the instrumentalization of colonial products of empire, including tropical fruit, chocolate, coffee, rubber, palm oil and sisal, as well as objectivized "blacks."

A typical theme for the evening was, for example, "Travels in the Tropics" or a "Voyage around Africa." On these occasions, the ballroom was transformed into a steamer of the Woermann Line, often with props created by local theater artists. Occasionally, even more well-known painters were enlisted to decorate

37 Bundesarchiv Berlin Lichterfelde (BAB), R1001/6693, FDKG Jahresbericht 1929-30, 31.

38 BAB R1001/6695, Bl. 99, Jahresbericht 1933-34.

39 BAB R8023/404, Bl. 41-2, N. von Steinmeister, "Deutsche Büchereien und Leseartikel in Afrika,” 1933; BAB R1001/6695, Bl. 219, Geschäftsbericht 1935-36.

40 Else Frobenius lists membership as 30,000 on 31 May 1936 in Frobenius, 30 Jahre koloniale Frauenarbeit (Berlin: Reichskolonialbund, 1936), 31.

41 Schilling, Postcolonial Germany, chapter 2. 
the walls with colonial-inspired motifs. At larger events, the "Arrival in Africa" was set up in a further ballroom. After being greeted with a speech about the significance of the former colonies for Germany and the importance of their reacquisition, guests "disembarked" and wandered among vines and palm trees, past a "native kraal" or an interactive pontok or tent, into "liveliness and frolicking," accompanied by an African band. Tables were decorated with miniature elephants, monkeys, palm trees, and "small chocolate negroes." In the "native bazaar," women dressed as "colored beauties" served tropical fruits such as bananas and oranges. Often, colorful advertisements would also adorn the ballroom. Further delights could be tasted at the "oriental"-style Mokkastübchen, where guests were served Germany's “own” coffee, cocoa, and other colonial products. Often the entertainment included a rendition of Zehn kleine Negerlein ("Ten Little Negroes"), as well as jazz music and an African dance or two.

Around three to four thousand people attended these sorts of events in major cities, most of them from the colonial, political and economic elite. Corporate sponsors included AEG, Deutsche Afrika Linien, Gasag, Deutsche Lufthansa, Daimler-Benz and Maggi. They supported primarily a move towards economic imperialism, although eventually economic arguments were also used as rationale for settler colonialism. An essential part of the marketing strategy of merchants selling tropical goods was making colonial products, usually revered as a luxury, appeal to a larger group of consumers. In this regard, the display and sale of colonial products at colonial balls was not only a way of solidifying bonds within the colonial elite. It was also intended to increase awareness of the colonial cause amongst a wider band of upper- and middle-class enthusiasts, expanding the circle of potential investors in a reinvigorated imperial project overseas.

Blacks (or representations of blacks) were the means by which colonial goods were sold. Though seldom credited with the production of colonial products, Africans were highly visible as abstract advertising symbols for them. Almost always depicted in a position of servitude, black men and women were shown carrying bananas, offering chocolates, and pouring coffee, an iconography continued from the nineteenth century. ${ }^{42}$ The trope of the African seems to have worked so well that it was extended to more ordinary household products which were also advertised at colonialist events. An exhibition stand in 1929 presented the following wares: "glistening negro caricatures, red-mouthed

42 David Ciarlo, "Rasse konsumieren. Von der exotischen zur kolonialen Imagination in der Bildreklame des Wilhelminischen Kaiserreichs," in Kundrus, Phantasiereiche, 135-179; see also Ciarlo, Advertising Empire (Cambridge, MA: Harvard University Press, 2011). 
and thick-lipped, tried skin cream, toothpaste or margarine, which was gobbled up by the packet." 43 Such images reinforced the stereotype of blacks as ridiculous, dirty, unhygienic, and uncivilized subjects who would benefit from a German sense of order, cleanliness, and hygiene. ${ }^{44}$

Examples from advertising for colonial products show a certain visual preoccupation with black and white skin in German culture in the 1920s and 1930s. A fixation on racial difference further informed the dream-world of colonial balls through another dream element: black performers. The choice of the term "black" rather than "African" is significant, because the idea of "black" took on a variety of different guises in German popular discourse at this time, including black Africans, African-Americans, and black Germans representing AfricanAmericans. Above all, although there may have been black Africans at German colonial balls, several reports suggest that it is more likely that the physical reality of "blackness" in the context of the colonial ball was a layer of black or brown greasepaint on white bodies. Like any dream, the colonial ball thus tried to make the abstract qualities of race more plastic and concrete, solidifying a positive and economically productive memory of German colonialism.

\section{1935-1945: Educational Maps}

Attempts to popularize a positive colonial memory were thus propagated during the Weimar years but had relatively little impact on a larger population. This began to change during the later National Socialist years. In response to the relative elitism of the colonial dream in the 1920s and early 1930s, the National Socialist government attempted to sell the colonial idea to "the masses" starting in the mid-1930s. Rather than organizing colonial balls, the Nazis staged events which were more accessible to a wider population. For example, a "colonial day" was held at the zoo in Berlin in 1937 under the motto "Everyone to Africa" (Jeder einmal in Afrika), and nation-wide colonial memorial days were established. ${ }^{45}$ Major colonial exhibitions were held in 1937 in Frankfurt and 1939 in Dresden, while a series of African-themed films hit the cinemas between 1938 and 1943.46

43 Mitteilungen des Frauenbunds der Deutschen Kolonialgesellschaft 12 (1929): 147.

44 For a similar phenomenon in British advertising, see Anne McClintock, Imperial Leather (New York: Routledge, 1995), 207-232.

45 Die Frau und die Kolonien 6 (1937), 95; Willi Walter Puls, Der koloniale Gedanke im Unterricht der Volksschule (Leipzig: Quelle \& Meyer, 1938), 147-148.

46 See Sabine Hake, "Mapping the Native Body: On Africa and the Colonial Film in the Third Reich”, in Friedrichsmeyer, Lennox, and Zantop, Imperialist Imagination, 164. 
Nowhere was colonialism more present, however, than in the classroom and, indeed, in the schoolbook and the accompanying maps. For it is through schoolbooks and didactic maps that an understanding of German history, including colonialism, was placed in every child's hands. As Simone Lässig and Karl Heinrich Pohl have noted, "textbook knowledge" is the result of contemporary discourse and therefore a reflection of zeitgeist. What is included in textbooks is "approved knowledge, accepted values, and popular memory," 47 a consensus among the political elite, and a cultural transfer between generations. ${ }^{48}$ It gives us insight into national stereotypes and provides points of comparison in times of social change. ${ }^{49}$ The schoolbook and the educational map are relatively durable objects of material culture; they accompany schoolchildren in their everyday lives, making regular trips between home and school, or private and public space. Their physical longevity also means that the pages themselves may last longer than the discourse in which they were written or drawn. In fact, at times of rapid regime change, textbooks and maps can become outdated before they have even been distributed.

During the Nazi era, colonialism was written into geography and history textbooks, but there were also special editions of pamphlets on colonial heroes which could be used as supplements to the schoolbook. As in the Weimar period, the writing style under the Nazis remained emotionally charged in an attempt to enthuse young minds for the colonial idea. In order to capture their imaginations even further, a series of short, inexpensive pamphlets (Schriften zur deutschen Erneuerung) published by Heinrich Handel, Breslau, was distributed to classrooms to supplement standard textbooks. These included readings on Lettow-Vorbeck as part of the "Heroes of the World War" series and a separate series on "Borderland and Overseas Germans" which included "Our Colonies Past and Future" and "Our Colonies during the World War."50 Additionally, teachers could use Schriften der Schülerbücherei, pamphlets which included colonial-themed titles such as Gustav Frenssen's Peter Moors Fahrt nach Südwest,

47 Simone Lässig and Karl Heinrich Pohl, "History Textbooks and Historical Scholarship in Germany,” History Workshop Journal 67 (2009): 125-126.

48 Saskia Handro and Bernd Schönemann, Geschichtsdidaktische Schulbuchforschung (Münster: Lit, 2006), 4.

49 Handro and Schönemann, Geschichtsdidaktische, 3.

50 Georg Vogel, Helden des Weltkrieges, 9th edn., 3 vols. (Breslau: Handel, 1943); Paul Schmidt, Unsere Kolonien in Vergangenheit und Zukunft, 16th edn. (Breslau: Handel, 1941); Walter Pardex, Unsere Kolonien im Weltkriege, 3rd edn. (Breslau: Handel, 1938). 
Bayer's Die Helden der Naukluft, and Lettow-Vorbeck's Heia Safari! ${ }^{51}$ Other independent titles include booklets of 50 or so pages on colonial pioneers as part of the Niedersächsische Jugendbücherei series published by Appelhans or a similar Erbe und Verpflichtung series published by Teubner..$^{52}$ Some teachers also used Hans Grimm's Volk ohne Raum as reading material for sixteen- and seventeenyear-olds. ${ }^{53}$

The Nazis incorporated arguments and views of the former colonial elite and added didactic messages of their own which resonated with the National Socialist world view. These included a new legitimization of colonial violence (absent from Weimar textbooks), the portrayal of the First World War in Africa as a "race war," and additional lessons for the Volksgemeinschaft from the colonial experience, including military readiness, heroic leadership, and the power of the collective will. In 1937, history and geography textbooks referred to areas that had been called the "former colonies" in the mid-1920s as "our colonies." Adopting the Nazi obsession with political geography, educational maps of Africa preached a falsified history to students. A 1941 map of Africa produced by Georg Westermann, Braunschweig (Fig. 1: Westermann's Generalkarte No. 2), for example, elided the past and the future, showing both the former colonies as German possessions, as well as reaching up just far enough to Europe to also reveal the recent (re-)conquest of Poland. Both the former and future "colonies" were highlighted in red in order to make them instantly recognizable to pupils.

Like the colonialist movements which preceded them, the Nazis may not have succeeded in convincing the entire German population of the need for colonies, but the lengths they went to in order to convince the German youth were nevertheless considerable. Targeting a vulnerable age group with the most basic tools, such as the schoolbook and map, was a highly efficient way of getting the message across. Nazi propagandists built on the work done previously by colonial enthusiasts during the Weimar period, and, indeed, the colonial story stayed much the same across both eras. After 1936, when the Nazis showed a greater

51 W. Rödiger, “Geschichte”, in Kurt Higelke, Neubau der Volksschularbeit, 2nd edn. (Leipzig: Julius Klinkhardt, 1941), 144.

52 E. g., Rudolf Krause, Kaufmann im Hererolande, Niedersächsische Jugendbücherei 2 (Brunswick: Appelhans, 1937); Carl Bradt, Robert Koch, Niedersächsische Jugendbücherei 5 (Brunswick: Appelhans, 1937, 1944); Rudolf Brauckmann, Karl Witt, and Walter Poppendieck, Kolonialdienst in der Südsee, Niedersächsische Jugendbücherei 9 (Brunswick: Appelhans, 1939); Hubert Coerver, Carl Peters (Leipzig/Berlin: Teubner, 1937); Heinz Nyszkiewicz and Bruno Dauch, Deutsches Land in Afrika (Leipzig/Berlin: Teubner, 1940).

53 H. Knust, “Grimms ‘Volk ohne Raum’ als Schullektüre,” Deutsches Bildungswesen (Oct. 1933): 265. 


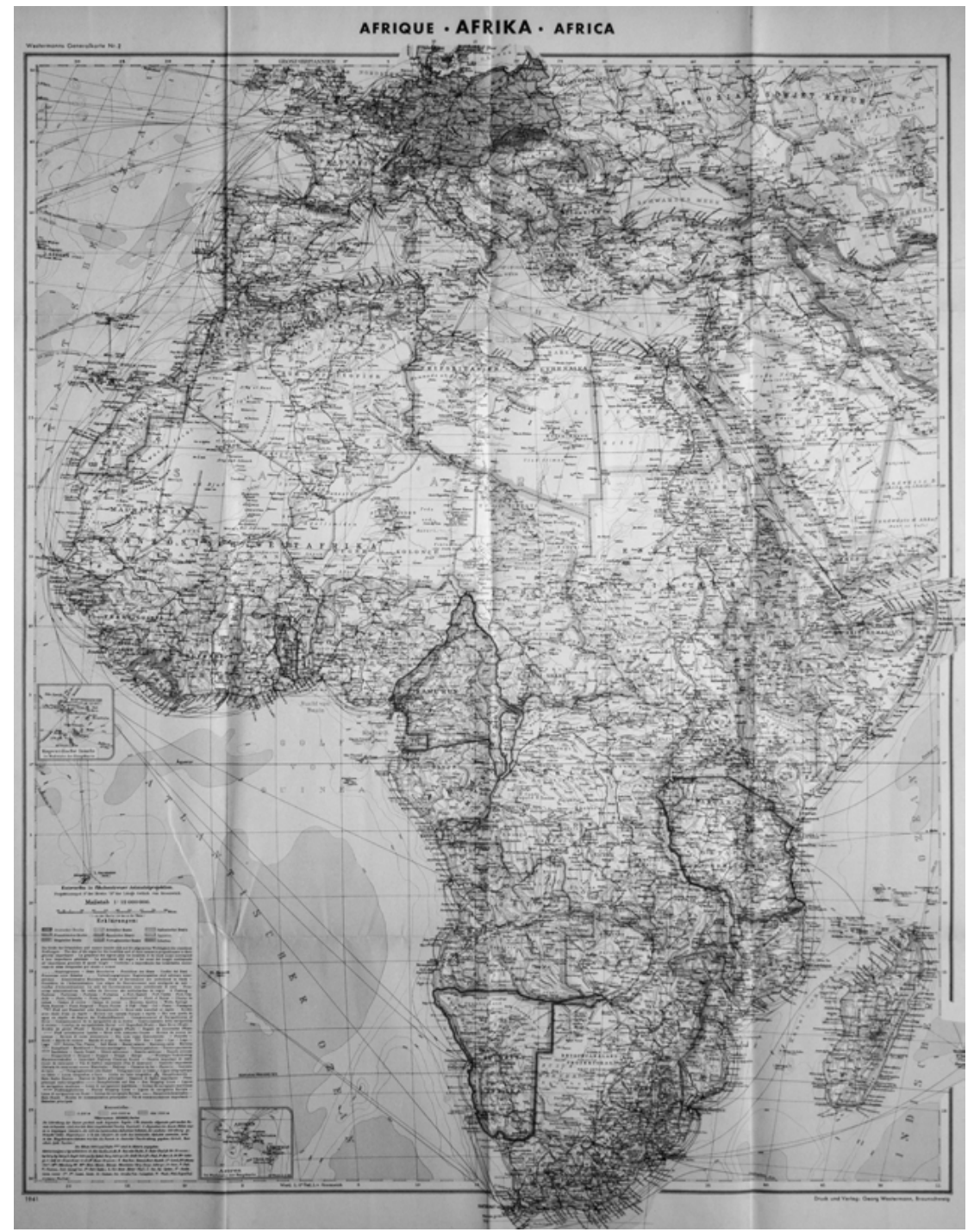

Fig. 1: A 1941 map for schoolchildren showing former colonies in Africa as German territory. Westermanns Generalkarten (Flemings Generalkarten) Nr. 2: Afrika, Braunschweig/Berlin/ Hamburg: Georg Westermann, 1941.

commitment to the colonial cause, however, significant changes were made in the way colonialism was taught. Learning about colonialism in the Third Reich thus taught students more than just the height of the Kilimanjaro, the 
date of the war with the Herero, or the name of the first German settlement in Africa. It was meant to fire their imagination and encourage their willingness to defend their nation's honor both at home and abroad. In many ways, it fulfilled government aims that history should have a "connection to the immediate present." 54 The colorful, visually engaging material used to communicate these messages no doubt made an impression on young minds, and indeed many of these themes stayed with the Hitler Youth generation for years to come.

\section{1949-1968: The State Gift}

For Germany, the immediate postwar period was a time of inwardness, both politically and socially. In the absence of a clearly defined German state, political interests in former overseas possessions were moot. Public memory of Germany's colonial past paled against the atrocities revealed in the more recent Nazi past, and was temporarily usurped by the lived experiences of rebuilding cities, reintegrating families, and relocating millions of people from Germany's former borderland territories in Europe. But it was not very long before Germany's colonial legacy resurfaced in public discourse. A deeper understanding of both East and West Germans' relation to the former colonies can be gleaned from analyzing objects that lie at the very heart of both the FRG and GDR's Afrikapolitik during the 1950s and 1960s. The official gifts from both states which were given to the former colonies at independence can provide valuable insights in this area.

In the context of Cold War competition, East and particularly West Germany's positions on the colonial past were constantly shifting, and the discourse surrounding gifts to former colonies reflect this complexity. More often than not, choosing the right gift was a cause of contention, hurried urgency and confusion. The rapid political developments in Africa kept ambassadors and consulates on their toes. West German representatives usually handed over gifts or gift certificates at the independence celebrations themselves, often presenting the item with a formal speech. Shortly thereafter, they would send over a team of delegates to secure a trade agreement with the new nation. Undeniably, for the West, development politics was, as the old colonial politics had been, a way of securing a market for exports. ${ }^{55}$ Accusations of "neo-colonialism" by the East were thus not entirely unfounded. As African nations made up only

54 "Reformvorschläge” (1933), 18, in Barbara Schneider, Die höhere Schule im Nationalsozialsimus (Cologne/Weimar/Vienna: Böhlau, 2000), 341.

55 Bastian Hein, Die Westdeutschen und die Dritte Welt (Munich: Oldenbourg, 2006), 26-28. 
two per cent of West German foreign trade in the mid-1960s, however, economic motivations cannot be considered the sole factor for the FRG's interest in the continent. ${ }^{56}$ West Germans were also motivated by pressure to participate in strategic development aid from other Western powers, particularly the United States. ${ }^{57}$

East Germany was much slower in combining gift-giving with development aid to African countries, causing it to resent West Germans' early ties with newly emergent states. While West Germany sent ambulances and promised harbor development projects, East Germany initially sent only a congratulatory telegram. It was a slow, cautious approach, as the GDR had no pre-existing relationships with Africa. It had rejected any ties to a former colonial relationship on ideological grounds and was not able to compete with the large financial grants and credits offered by the FRG. Nevertheless, as the FRG's state gifts were often a precursor to more extensive development aid, so the GDR's telegram was often a gateway to economic or cultural agreements, or even a "solidarity program." As was the case for West German gifts, sending the congratulatory telegram was a ritual which served to promote the GDR as the one "true" Germany as much as it was meant to actually help Africans. As Marcel Mauss observed, an intense rivalry exists within and between societies to bring about exchanges of the most valuable things, for this signifies wealth and can "attract and dazzle" the other party, eventually winning them over as allies. ${ }^{58}$ Such a rivalry eventually played itself out between East and West Germany in the selection and delivery of state gifts, for both wished to win over the newly independent nations as allies in the Cold War.

But beyond Cold War politics, a key point informing this rivalry was the dilemma of how to remember Germany's colonial past. West Germany, although aware of the negative connotations of colonialism in an age of mass decolonization, could not help but try to assume the legacy of a "good colonialist" in Africa. Its cultural memory was constructed by the convictions of government ambassadors and advisers who had been active in the former colonies before 1945, as well as alleged testimonies by former colonial subjects themselves. ${ }^{59}$ Gifts from West Germany thus included objects which referenced the "good old days" of German colonialism, a period of "scientific colonialism" in which the Germans provided medical care, epitomized by the research of Robert Koch and Albert Schweitzer.

56 Rainer Tetzlaff, “Grundzüge und Hintergründe Bonner Afrika-Politik,” in Helmut Bley and Rainer Tetzlaff, Afrika und Bonn (Reinbek bei Hamburg: Rowohlt, 1978), 30.

57 Hein, Die Westdeutschen, 38.

58 Marcel Mauss, The Gift, trans. W.D. Halls (London: Routledge, 1990), 28.

59 See Schilling, Postcolonial Germany, chapter 4. 
Cameroon, for example received a Klinomobil, a mobile medical station, while Tanganyika received an X-ray unit, and Rwanda and Burundi received ambulances. Not to be overlooked is the fact that all of these gifts are material objects, objects which could be inscribed with personal messages of congratulations but which also physically embodied a special relationship between the two nations which dated back to the colonial period.

In contrast to the FRG, East Germany claimed to have broken with the colonial past completely. Its stance left relations to the former colonies dangling in a state of uncertainty, ostensibly with no shared memories-positive or negativeto build upon. But over time, East Germans' denial and repression of colonial memory was at times punctuated by a very limited recognition. East German congratulations started with Glückwunschbriefe, presented like gifts by a visiting diplomat but eschewing the crass materialism of the capitalist West. Eventually, however, the GDR also favored material signs of appreciation, notably with a gift of a printing press to Tanganyika in 1962, presented at the one-year anniversary of independence. ${ }^{60}$ As with gifts given by West Germany, the gift given by the GDR appears to represent a paternalistic kind of relationship with the new state which implicitly references colonial times: a gift of "the word," Western education and technology. Interestingly, though, like the West German gift at independence, this state gift was selected in response to a wish expressed by the Tanganyikan government, specifically, Foreign Minister Oscar Kambona during his visit to the GDR in April 1962. ${ }^{61}$

The changing face of public memory of German colonialism since the end of the First World War has now been traced, noting where and how this collective memory was upheld and manipulated to fit into the dominant national paradigms. It is clear that, even after the Second World War, the public memory of colonialism was still making important appearances. And yet, it had changed: by the 1960s, there were rising uncertainties about moral implications of a colonial past, as well as an entirely novel context of Cold War alliances which framed colonial memory.

60 Auswärtiges Amt (AA) MfAA/A15068, Bl. 201-2, Direktive für die Delegation nach Ostafrika im Dezember 1963, 29 Nov. 1963.

61 AA MfAA/A15067, Bl. 244, MfAA an Büro des Bevollmächtigten der DDR in der VAR, betr. Tanganyika, 4 May 1963. 


\section{1968-1990: The Empty Plinth}

One of the most poignant moments of German postcolonial history, analyzed by several historians, is when students of the University of Hamburg tore down the statue of the colonial explorer Hermann von Wissmann in 1967-8 as part of a larger Denkmalsturz movement. ${ }^{62}$ The fall of the Wissmann statue is symbolic of a broader trend concerning German colonial memory after 1968. In spite of several moments of colonial remembering after 1968, Germany's colonial past ceased to play a significant role in public space and therefore receded from the nation's (or, rather, both nations') collective memory. During this period the memory of colonialism may therefore be considered not as an artefact, but as an absence-an empty plinth where once a colonial monument stood. This is not to say that there was no interaction with the colonial past at all. In fact three potential nodes of memory did develop during this time through student activism and street protest, the work of East and West German historians, and the controversy surrounding Southwest Africa's independence. The difference from previous foci of memory, however, is that this memory no longer informed the national, collective conception of the past; it did not exist on the level of politics and government, nor did it have any real meaning in the socio-cultural space. It was a memory not internalized, but employed by small groups sharing diverse special interests, causes not necessarily directly related to German colonialism at all. These groups confronted the German colonial past in the present, but these were localized, fragmented, incomplete encounters, not tied together in a master narrative as public or national memory is. Colonial memory had thus moved from the monumental to the local, and likewise from an era of material memories to an era of traces, ghosts, and whispers increasingly related to the present rather than the past. Colonialism ceased to be a memory anchored in material relics but instead became an idea, a battle-cry, a symbol, a word. In public space at least, it moved from three to two dimensions.

In Germany, the public memory of the colonial past faded after 1968. This was because effective memory is dependent on large part on effective retrieval -the ability to call up encoded memories quickly. Not only individual memory, but also collective memory requires some outside impulse, a mnemonic device,

62 Joachim Zeller, Kolonialdenkmäler (Frankfurt am Main: IKO, 1999); Wolfgang Speitkamp, Denkmalsturz (Göttingen: Vandenhoeck \& Ruprecht, 1997); Ingo Cornils, "Denkmalsturz: The German Student Movement and German Colonialism," in Michael Perraudin and Jürgen Zimmerer, German Colonialism and National Identity (New York/London: Routledge, 2011), 197-212; Quinn Slobodian, Foreign Front (Durham/London: Duke University Press, 2012). 
in order to be sustained. With the absence of triggers for remembering, including the physical destruction of monuments to the colonial past, the German collective memory of colonialism was rendered a taboo and subsumed in a torrent of other national memories, many of them more recent. ${ }^{63}$ As Viktor Mayer-Schönberger points out, "Even though we may have stored it...information that cannot be retrieved easily in practical terms is no different from having been forgotten." ${ }^{64}$ Without things, historical memory-like individual memory-has no longevity.

\section{Coda 1: Family Memory}

That would be the end of the story-except for two codas. The first is the remarkable resilience of family memories of the colonial past, which I have investigated in more detail elsewhere. ${ }^{65}$ These can be divided roughly into four generations: colonial actors (born c. 1850s-1880s), who brought back ethnographic items and hunting trophies which served as objects of memory and eventually became, over the years, decontextualized ornaments. The next generation, a "decolonized" generation (born c. 1880s-1910s), added photographs, diaries, and more ethnographic objects, preserving them together with older items to combat a sense of loss and generate hope for a possible reclaiming of the former colonies in the future. For the next "postcolonial" generation (born c. 1920s-1940s), the memory of colonialism was deeply enmeshed with memories of National Socialism and wrought with a mixture of pride and guilt. This generation is often now charged with managing the family archive, arranging and contextualizing photographs, particularly portraits displaying a clear iconography of colonialism, including pith helmets, hunting trophies, lush vegetation, all of which have become markers of colonial identity within the family. Other items, such as gifts from the former colonies, are kept because they represent the essential "otherness" of colonial ancestors, who are more often than not remembered as quirky, harmless characters. Finally, the "extra-colonials" (born c. 1950s-1970s) are doubly impacted by silencing of colonial memory within the family and lack of emphasis on colonial history in education and public until very recently. By

63 Joachim Zeller also suggests that the disappearance of colonial monuments from public space after 1968 may well facilitate forgetting of, and critical engagement with, the colonial era. Zeller, Kolonialdenkmäler, 214-215.

64 Viktor Mayer-Schönberger, Delete (Princeton/Oxford: Princeton University Press, 2009).

65 Schilling, Postcolonial Germany, chapter 6; Schilling, "Imperial Heirlooms," Journal of Imperial and Commonwealth History 41,4 (2013): 663-682. 
engaging with both material and immaterial memories of the colonial past, this generation presents a clear potential for "working through" the legacies of German colonialism, perhaps even adding new layers of memory and material culture to the family archive. Together, these generations have constructed private archives of artefacts, stories, texts, and photographs which form an important part of German colonial memory, archives which at times resonates with but at other times runs counter to colonial memory in the public sphere.

Over the years, two major trends have emerged: first, the narratives produced in colonial families have become increasingly influenced by public memory; and, secondly, private, family memory's bearing on public memory has decreased. In spite of some similarities and overlaps, the memory of German colonialism is thus ultimately unlike that of Nazism, which has been increasingly infused with private recollections brought to light in published sources, talks, school projects, and similar initiatives. At the same time, because a much smaller segment of the population was involved in the colonial project, the private memories of colonialism could continue, not without impact from outside but certainly without such a full-scale intrusion as the national "working through" of the Nazi past.

In both Germanies, then, the memory of colonialism, although contested at times, frequently appeared in public life even beyond 1945. Private family memory, on the other hand, was more hidden, lying just below the surface of national narratives, in what one might call a "subterranean" space filled with odd pieces of material culture, a few anecdotes, and incomplete recollections. This eclecticism is a typical characteristic of collective memory in the family. Grandparents, as Maurice Halbwachs argues, can only communicate their family memory to their grandchildren in fragmentary ways, "within the interstices of the present family," never as a totality. ${ }^{66}$ Moreover, as Angela Keppler has posited, the narration of what she calls "family history" is defined by occasional acts of remembering and can therefore by its very nature never be seen as unified whole. ${ }^{67} \mathrm{Fi}$ nally, the substance of family memory lies not in the profound, but, rather, in the profane. Keppler claims that family memory is above all constituted by "little" stories. ${ }^{68}$ Colonial family memory, like other family memory, is a series of these sorts of material and immaterial fragments. In the absence of a "monumental," internationally recognized narrative of empire, and in the overwhelming absence of public monuments still actively associated with colonialism, "little" pri-

66 Maurice Halbwachs, On Collective Memory, trans. L. A. Coser (Chicago/London: University of Chicago Press, 1992), 77-78.

67 Angela Keppler, Tischgespräche (Frankfurt am Main: Suhrkamp, 1995), 207.

68 Keppler, Tischgespräche, 186. 
vate memories have become the primary means of engagement with Germany's colonial legacy.

\section{Coda 2: Postcolonial Heritage in Former Colonies}

Therefore, German colonialism, though begun in the nineteenth century, is a twentieth century phenomenon, not (only) because it witnessed "the first genocide of the twentieth century," but because its memory has played a decisive role in political, cultural and social-public and private-relations in Germany at key points throughout the twentieth century. The second coda to keep in mind, however, is the trajectory and continuation of colonial memory in the former colonies and its complications in terms of material heritage and postcolonial tourism. Of particular interest to me in my current research is the issue of former colonial homes in Namibia and other former European colonies in Africa. Colonial memory in the former Southwest Africa has been addressed by experts on Namibian history and anthropology such as Larissa Förster, Reinhart Kössler, Henning Melber, and other scholars. What is particularly poignant, however, is how both the German idea of Heimat and the physical traces of colonial-era homes complicate discussions on postcolonial heritage in the region.

Despite the recent changes to the urban landscape in places like Windhoek, German architecture is still one of the most visible traces of memory of colonial times in Namibia. ${ }^{69}$ The National Heritage Council of Namibia lists 32 buildings from the German colonial era, ten of which were private residences, as National Monuments. All of these buildings were declared national heritage monuments by the National Monuments Council of South Africa in the 1960s through 1980s. They now have various uses, including as storage rooms, shops, hostels, museums, and guest houses. ${ }^{70}$ Some of these are owned privately and have been preserved through private initiatives, such as the Consolidated Diamond Mines (NamDeb) which renovated the Goerke Haus (or Magistrate's House) in Lüderitz and one representative house in the nearby "ghost town," Kolmanskuppe.

69 On German colonial architecture in Namibia, see for example, Itohan Osayimwese, "Colonialism at the Center," PhD dissertation (University of Michigan, 2008); Osayimwese, "Prolegomenon to an alternative genealogy of German modernism," Journal of Architecture 18,6 (2013): 835 874; Walter Peters, Baukunst in Südwestafrika,1884-1914 (Windhoek: SWA Scientific Society, 1981); Peters, "Wilhelminian Historicism and Objectivity", Restorica 14 (Oct. 1983): 13-23; Peters, "Das Verandenhaus. Beispiel einer klimatisch wohltemperierten Bauweise," in Klaus Hess and Klaus Becker, Vom Schutzgebiet bis Namibia (Windhoek: Klaus Hess, 2002), 242-243.

70 National Heritage Council of Namibia, www.nhc-nam.org, accessed 4 June 2014. 
In popular tourist towns such as Swakopmund and Lüderitz public debate about the preservation of German colonial architecture and the general architectural "look" of the town has increased in recent years. Part of the reason colonial-era buildings here have not been bulldozed, I would suggest, is that this architecture is thought to "characterize" the towns' old-world "charm," something which makes them eminently attractive to tourists. In addition, any major changes to smaller townscapes would almost certainly run up against German-speaking grassroots initiatives, as has already happened in Swakopmund. ${ }^{71}$

Out in the veld, the owners of safari lodges are also aware of the appeal of a historic, "colonial” style. But German architecture is not just a tourist trap-it has played a significant role in the memory of the past among the German settler community both in Namibia and in Germany. And because of that, rather than being an ending point, it is perhaps an ideal starting point for thinking about a more entangled memory of colonialism in both former colony and metropole.

\section{Works cited}

Adorno, Theodor. What does coming to terms with the past mean? In Bitburg in Moral and Political Perspective, edited by Geoffrey Hartman, 114-129. Bloomington: Indiana University Press, 1986.

Albrecht, Monika. Postcolonialism and migration into Germany's colonial past. German Life and Letters 65,3 (July 2012): 363-377.

Ames, Eric, Marcia Klotz and Lora Wildenthal. Germany's Colonial Pasts. Lincoln: University of Nebraska Press, 2005.

Angebauer, Karl. Ovambo. 15 Jahre unter Kaffern, Buschleuten und Bezirksamtmännern.

Berlin: Scherl, 1927.

Appadurai, Arjun, The Social Life of Things: Commodities in Cultural Perspective. Cambridge:

Cambridge University Press, 1986.

Aschenborn, Hans Anton. Die Farm im Steppenlande. 11 Jahre Farmerleben und Jagd in Afrika. Neudamm: Neumann, 1925.

Assmann, Jan. Stein und Zeit. Das ‘monumentale’ Gedächtnis der altägyptischen Kultur. In Kultur und Gedächtnis, edited by Jan Assmann and Tonio Hölscher, 87-114. Frankfurt am Main: Surhkamp, 1988.

Assmann, Jan and Jan Czaplicka. Collective Memory and Cultural Identity. New German Critique 65 (Spring-Summer 1995): 125-133.

Auswärtiges Amt (AA), Ministerium für Auswärtige Angelegenheiten, MfAA/A15068

Tanganyika/Sansibar, MfAA/A15067 Tanganyika.

71 E. g., Maggi Barnard, "Fears rife at Swakopmund that heritage being 'defaced," The Namibian, 14 July 2004: www.namibian.com.na/index.php?id=5637\&page=archive-read, accessed 4 June 2014. 
Baranowski, Shelley. Nazi Empire: German Colonialism and Imperialism from Bismarck to Hitler. Cambridge/New York: Cambridge University Press, 2011.

Barnard, Maggi. Fears rife at Swakopmund that heritage being 'defaced'. The Namibian 14 July 2004: www.namibian.com.na/index.php?id=5637\&page=archive-read [Accessed 5 June 2014].

Bechhaus-Gerst, Marianne and Sunna Giesecke. Koloniale und postkoloniale Konstruktionen von Afrika und Menschen afrikanischer Herkunft in der deutschen Alltagskultur. Frankfurt am Main/New York: Lang, 2007.

Bechhaus-Gerst, Marianne and Reinhard Klein-Arendt. Afrikanerlnnen in Deutschland und schwarze Deutsche. Münster: Lit, 2004.

Bechhaus-Gerst, Marianne and Reinhard Klein-Arendt. Die (koloniale) Begegnung: AfrikanerInnen in Deutschland, 1880-1945, Deutsche in Afrika, 1880-1918. Frankfurt am Main: Lang, 2003.

Bley, Helmut and Rainer Tetzlaff, Afrika und Bonn. Versäumnisse und Zwänge deutscher Afrika-Politik. Reinbek bei Hamburg: Rowohlt, 1978.

Bradt, Carl. Robert Koch. Niedersächsische Jugendbücherei 5. Brunswick: Appelhans, 1937, 1944.

Brauckmann, Rudolf, Karl Witt, and Walter Poppendieck, Kolonialdienst in der Südsee. Brieftagebuch des Kolonialsekretärs Rudolf Brauckmann aus Uslar, gefallen im Kampf mit Aufständischen auf Ponape (Ost-Karolinen) am 18. Oktober 1910. Niedersächsische Jugendbücherei 9. Brunswick: Appelhans, 1939.

Brohm, Berthold. Das Buch in der Krise. Studien zur Buchhandelsgeschichte der Weimarer Republik. Archiv für Geschichte des Buchwesens 51 (1999): 256-296.

Buchhändlergilde-Blatt 3 (1920).

Buchhändlergilde-Blatt 10 (1925).

Bundesarchiv Berlin Lichterfelde (BAB), R1001/6693, R1001/6695, R8023/404,

Campt, Tina. Other Germans: Black Germans and the Politics of Race, Gender and Memory in the Third Reich. Ann Arbor: University of Michigan Press, 2004.

Castro Varela, María do Mar and Nikita Dhawan. Mission Impossible: Postkoloniale Theorie im deutschsprachigen Raum? In Postkoloniale Soziologie, edited by Julia Reuter and Paula-Irene Villa, 303-330. Bielefeld: Transcript, 2010.

Ciarlo, David. Advertising Empire: Race and Visual Culture in Imperial Germany. Cambridge, MA: Harvard University Press, 2011.

Coerver, Hubert. Carl Peters: ein Kämpfer um deutschen Raum. Leipzig/Berlin: Teubner, 1937.

Conrad, Sebastian. Deutsche Kolonialgeschichte. Munich: C. H. Beck, 2008.

Conrad, Sebastian and Jürgen Osterhammel. Das Kaiserreich transnational. Deutschland in der Welt, 1871-1914. Göttingen: Vandenhoeck \& Ruprecht, 2004.

Cyber-Nomads/Öffentlichkeit gegen Gewalt. The Black Book. Frankfurt am Main/London: IKO, 2004.

Danton, G. H. Hans Grimms Volk ohne Raum. Monatshefte für deutschen Unterricht 27,2 (Feb. 1935): 33-43.

Eggers, Maureen Maisha, Grada Kilomba, Peggy Piesche and Susan Arndt. Mythen, Masken und Subjekte: kritische Weissseinforschung in Deutschland. Münster: Unrast, 2006.

Eley, Geoff and Bradley Naranch. German Colonialism in a Global Age. Durham: Duke University Press, 2014.

Die Frau und die Kolonien 6 (1937). 
Friedrichsmeyer, Sara, Sara Lennox and Susanne Zantop. The Imperialist Imagination:

German Colonialism and its Legacies. Ann Arbor: University of Michigan Press, 1998.

Frobenius, Else. 30 Jahre koloniale Frauenarbeit. Berlin: Reichskolonialbund, 1936.

Furber, David and Wendy Lower. Colonialism and genocide in Nazi-occupied Poland and Ukraine. In Empire, Colony, Genocide: Conquest, Occupation, and Subaltern Resistance in World History, edited by A. Dirk Moses, 372-400. New York/Oxford: Berghahn Books, 2008.

Gosden, Chris and Chantal Knowles. Collecting Colonialism: Material Culture and Colonial Change. Oxford/New York: Berg, 2001.

Grosse, Pascal. From colonialism to National Socialism to postcolonialism. Postcolonial Studies 9,1 (2006): 35-52.

Ha, Kien Nghi, Nicola Lauré al-Samarai and Sheila Mysorekar. re/visionen. Postkoloniale Perspektiven von People of Color auf Rassismus, Kulturpolitik und Widerstand in Deutschland. Münster: Unrast, 2007.

Halbwachs, Maurice. On Collective Memory. Translated by L. A. Coser. Chicago/London: University of Chicago Press, 1992.

Handro, Saskia and Bernd Schönemann. Geschichtsdidaktische Schulbuchforschung Münster: Lit, 2006.

Harvey, Karen. History and Material Culture. Abingdon: Routledge, 2009.

Hauer, August. Kumbuke. Erlebnisse eines Arztes in Deutsch-Ostafrika. 4th edition. Berlin: Hobbing, 1926.

Hein, Bastian. Die Westdeutschen und die Dritte Welt. Entwicklungspolitik und Entwicklungsdienste zwischen Reform und Revolte 1959-1974. Munich: Oldenbourg, 2006.

Higelke, Kurt. Neubau der Volksschularbeit. Plan, Stoff und Gestaltung nach den neuen Richtlinien des Reichserziehungsministeriums. 2nd edition. Leipzig: Julius Klinkhardt, 1941.

Hull, Isabel. Absolute Destruction: Military Culture and the Practice of War in Imperial Germany. Ithaca/London: Cornell University Press, 2005.

Inhülsen, Otto. Wir ritten für Deutsch-Ostafrika. Leipzig: V. Hase \& Koehler 1926.

Jarausch, Konrad and Michael Geyer. Shattered Past: Reconstructing German Histories. Princeton: Princeton University Press, 2003.

Jones, Andrew. Memory and Material Culture: Tracing the Past in Prehistoric Europe. Cambridge/New York: Cambridge University Press, 2007.

Keppler, Angela. Tischgespräche. Über Formen kommunikativer Vergemeinschaftung am Beispiel der Konversation in Familien. Frankfurt am Main: Suhrkamp, 1995.

Klotz, Marcia. Global visions: from the colonial to the National Socialist world. European Studies Journal. Special Issue: German Colonialism: Another Sonderweg? 16,2 (Fall 1999): 37-68.

Knust, H. Grimms ‘Volk ohne Raum' als Schullektüre. Deutsches Bildungswesen (Oct. 1933): 265-271.

Koch, Karl W. H. Im toten Busch: Kameruner Erzählungen. Leipzig: Voigtländer, 1922.

Krause, Rudolf. Kaufmann im Hererolande. Ein niedersächsischer Bauernjunge wird Großkaufmann in Deutsch-Südwest-Afrika. Niedersächsische Jugendbücherei 2. Brunswick: Appelhans, 1937.

Kühnhold, Grete. In Friedens- und Kriegszeiten in Kamerun. Berlin: Scherl, 1917. 
Kundrus, Birthe. Kontinuitäten, Parallelen, Rezeptionen. Überlegungen zur 'Kolonialisierung' des Nationalsozialismus. Werkstatt Geschichte 43 (2006): 45-62.

Kundrus, Birthe. Moderne Imperialisten. Das Kaiserreich im Spiegel seiner Kolonien. Cologne: Böhlau, 2003.

Kundrus, Birthe. Phantasiereiche: zur Kulturgeschichte des deutschen Kolonialismus. Frankfurt am Main: Campus, 2003.

Lässig, Simone and Karl Heinrich Pohl. History Textbooks and Historical Scholarship in Germany. History Workshop Journal 67 (2009), 125-139.

Langbehn, Volker. German Colonialism, Visual Culture, and Modern Memory. New York/London: Routledge, 2010.

Langbehn, Volker and Mohammad Salama. German Colonialism: Race, the Holocaust, and Postwar Germany. New York: Columbia University Press, 2011.

Lennox, Sara. Postcolonial writing in Germany. In Cambridge History of Postcolonial Literature, edited by Ato Quayson, 620-648. Cambridge: Cambridge University Press, 2012.

Lewerenz, Susann. Die Deutsche Afrika-Schau (1935-1940). Rassismus, kolonialrevisionismus und postkoloniale Auseinandersetzungen im nationalsozialistischen Deutschland. Frankfurt am Main: Lang, 2006.

Lindner, Ulrike. Koloniale Begegnungen. Deutschland und Großbritannien als Imperialmächte in Afrika 1880-1914. Frankfurt am Main/New York: Campus, 2011.

Linne, Karsten. Deutschland jenseits des Äquators: die NS-Kolonialplanungen für Afrika. Berlin: Ch. Links, 2008.

Lutz, Helma and Kathrin Gawarecki, Kolonialismus und Erinnerungskultur: die Kolonialvergangenheit im kollektiven Gedächtnis der deutschen und niederländischen Einwanderungsgesellschaft. Münster: Waxmann, 2005.

Malinowski, Stephan and Robert Gerwarth. Hannah Arendt's ghosts: reflections on the disputable path from Windhoek to Auschwitz. Central European History 42 (2009): 279300.

Maß, Sandra. Weiße Helden, schwarze Krieger. Zur Geschichte kolonialer Männlichkeit in Deutschland 1918-1964. Cologne: Böhlau, 2006.

Mauss, Marcel. The Gift: the Form and Reason for Exchange in Archaic Societies. Translated by W.D. Halls. London: Routledge, 1990.

Mayer-Schönberger, Viktor. Delete: the Virtue of Forgetting in the Digital Age.

Princeton/Oxford: Princeton University Press, 2009.

Mazower, Mark. Dark Continent: Europe's Twentieth Century. New York: Random House, 1998.

McClintock, Anne. Imperial Leather: Race, Gender and Sexuality in the Imperial Contest. New York: Routledge, 1995.

Mitteilungen des Frauenbunds der Deutschen Kolonialgesellschaft 12 (1929).

National Heritage Council of Namibia: www.nhc-nam.org [Accessed 5 June 2014].

Nyszkiewicz, Heinz and Bruno Dauch, Deutsches Land in Afrika. Bilder aus den deutschen Kolonien. Leipzig/Berlin: Teubner, 1940.

Osayimwese, Itohan. Colonialism at the center: German colonial architecture and the design reform movement, 1828-1914. PhD dissertation, University of Michigan, 2008.

Osayimwese, Itohan. Prolegomenon to an alternative genealogy of German modernism: German architects' encounters with world cultures c. 1900. Journal of Architecture 18,6 (2013): 835-874. 
Pardex, Walter. Unsere Kolonien im Weltkriege. 3rd edition. Breslau: Handel, 1938.

Penny, H. Glenn. Objects of Culture: Ethnology and Ethnographic Museums in Imperial

Germany. Chapel Hill/London: University of North Carolina Press, 2003.

Penny, H. Glenn and Matti Bunzl. Worldly Provincialism: German Anthropology in the Age of Empire. Ann Arbor: University of Michigan Press, 2003.

Peters, Walter. Baukunst in Südwestafrika,1884-1914. Windhoek: SWA Scientific Society, 1981.

Peters, Walter. Das Verandenhaus. Beispiel einer klimatisch wohltemperierten Bauweise. In Vom Schutzgebiet bis Namibia, edited by Klaus Hess and Klaus Becker, 240-247. Windhoek: Klaus Hess Verlag, 2002.

Peters, Walter. Wilhelminian historicism and objectivity: the reception of German architecture during the period 1882 to 1914 in the former German Southwest Africa (Namibia). Restorica 14 (Oct. 1983): 13-23.

Poiger, Uta. Imperialism and empire in twentieth-century Germany. History and Memory 17,12 (Spring-Summer 2005): 117-143.

Poley, Jared. Decolonization in Germany: Weimar Narratives of Colonial Loss and Foreign Occupation. Oxford/New York: Lang, 2005.

Prüße, Albert. Zwanzig Jahre Ansiedler in Deutsch-Ostafrika. Stuttgart: Strecke \& Schröder, 1929.

Puls, Willi Walter. Der koloniale Gedanke im Unterricht der Volksschule. Leipzig: Quelle \& Meyer, 1938.

Richards, Donald Ray. The German Bestseller in the 20th Century. Bern: Lang, 1968.

Schilling, Britta. German postcolonialism in four dimensions: a historical perspective. Postcolonial Studies 18,4 (2015): 427-439.

Schilling, Britta. Imperial heirlooms: the private memory of colonialism in Germany. Journal of Imperial and Commonwealth History 41,4 (2013): 663-682.

Schilling, Britta. Postcolonial Germany: Memories of Empire in a Decolonized Nation. Oxford: Oxford University Press, 2014.

Schmidt, Paul. Unsere Kolonien in Vergangenheit und Zukunft. 16th edition. Breslau: Handel, 1941.

Schneider, Barbara. Die höhere Schule im Nationalsozialismus. Zur Ideologisierung von Bildung und Erziehung. Cologne/Weimar/Vienna: Böhlau, 2000.

Schneider-Waterberg, H. R. Der Wahrheit eine Gasse. Swakopmund: Gesellschaft für Wissenschaftliche Entwicklung, 2006.

Schwerbrock, Wolfgang, Hans Thiekötter and Wilhelm Lehmann. Safari Verlag 1921-1961: Die Wandlung unseres Bildungsgutes in 40 Jahren. Berlin: Safari, 1961.

Slobodian, Quinn. Foreign Front: Third World Politics in Sixties West Germany. Durham/London: Duke University Press, 2012.

Smith, Woodruff . The Colonial Novel as Political Propaganda: Hans Grimm's Volk ohne Raum'. German Studies Review 6,2 (May 1983): 215-35.

South-West Africa Administrator's Office. Report on the Natives of South-West Africa and their Treatment by Germany. London: His Majesty's Stationery Office, 1918. [British Parliamentary Papers Cd. 9146].

Speitkamp, Wolfgang. Denkmalsturz: zur Konfliktgeschichte politischer Symbolik. Göttingen: Vandenhoeck \& Ruprecht, 1997.

Steedman, Carolyn. What a rag rug means. Journal of Material Culture 3,3 (Nov. 1998): 259281. 
Steyerl, Hito, Encarnación Gutiérrez Rodríguez and Kien Nghi Ha. Spricht die Subalterne deutsch? Migration und postkoloniale Kritik. $2^{\text {nd }}$ edition. Münster: Unrast, 2012.

Stoecker, Holger, Thomas Schnalke and Andreas Winkelmann. Sammeln, Erforschen, Zurückgeben? Menschliche Gebeine aus der Kolonialzeit in akademischen und musealen Sammlungen. Berlin: Ch. Links, 2013.

Thomas, Nicholas. Entangled Objects: Exchange, Material Culture and Colonialism in the Pacific. Cambridge, MA/London: Harvard University Press, 1991.

Van Laak, Dirk. Imperiale Infrastrukur. Deutsche Planungen für eine Erschließung Afrikas 1880 bis 1960. Paderborn: F. Schöningh, 2004.

Verber, Jason. The conundrum of colonialism in postwar Germany. PhD dissertation, University of lowa, 2010.

Vogel, Georg. Helden des Weltkrieges: ein Lesebogen für die deutsche Jugend. 9th edition. 3 vols. Breslau: Handel, 1943.

Wildenthal, Lora. Notes on a history of 'imperial turns' in modern Germany. In After the Imperial Turn: Thinking with and through the Nation, edited by Antoinette Burton, 14556. Durham /London: Duke University Press, 2003.

Zeller, Joachim. Kolonialdenkmäler und Geschichtsbewußtsein. Eine Untersuchung der Kolonialdeutschen Erinnerungskultur. Frankfurt am Main: IKO, 1999.

Zemon Davis, Natalie. Trickster Travels: a Sixteenth-Century Muslim between Worlds. London: Faber, 2007.

Zimmerer, Jürgen. Colonialism and the Holocaust-Toward an Archeology of Genocide. Development Dialogue 50 (Dec. 2008): 95-123.

Zimmerer, Jürgen. Deutsche Herrschaft über Afrikaner: staatlicher Machtanspruch und Wirklichkeit im kolonialen Namibia. Münster: Lit, 2001.

Zimmerer Jürgen. Kein Platz an der Sonne: Erinnerungsorte der deutschen Kolonialgeschichte. Frankfurt am Main: Campus, 2013.

Zimmerer, Jürgen and Michael Perraudin. German Colonialism and National Identity. London: Routledge, 2010.

Zimmerer, Jürgen and Joachim Zeller. Völkermord in Deutsch-Südwestafrika: der Kolonialkrieg (1904-1908) in Namibia und seine Folgen. Berlin: Ch. Links, 2003. 